\title{
Adhesives for On-Site Rehabilitation of Timber Structures
}

\author{
Helena Cruz ${ }^{\mathrm{a}, *}$ and João Custódio ${ }^{\mathrm{b}}$ \\ ${ }^{a}$ Laboratório Nacional de Engenharia Civil — LNEC, Structures Department, Av. Brasil 101, \\ 1700-066 Lisboa, Portugal \\ ${ }^{\mathrm{b}}$ Laboratório Nacional de Engenharia Civil — LNEC, Materials Department, Av. Brasil 101,
} 1700-066 Lisboa, Portugal

\begin{abstract}
The use of adhesives to produce assembled structural joints in the building industry is increasing, particularly in the context of on-site rehabilitation of timber structures. On their own or together with steel or fibre reinforced polymer composite connecting materials, adhesives can provide low intrusive, fast, versatile and effective on-site repair or reinforcement interventions to timber structures. Most common applications involve sealing and repair of cracks, drying fissures and delamination of glued laminated members; replacement of decayed beam ends; strengthening of timber members; and repair and strengthening of mechanical timber joints. The performance of bonded joints highly depends on their design and detailing, surfaces preparation, selection and application of adhesives, and full compliance with their cure schedule. Therefore, the work should be carried out by well-informed, trained and certified operators following a Quality Assurance Program to ensure satisfactory end-product strength and durability.

Despite some recent developments, the exploitation of the full potential for on-site bonded joints is mainly restrained at present by the lack of structural design guidance, standards for durability assessment and onsite acceptance testing.

This article discusses briefly the use of adhesives on the construction site in the context of structural repair and reinforcement; the requirements and practical difficulties in the work on site with regards to the strength and durability of the rehabilitated timber structure; and the consequent need for quality control. It also highlights the characteristics and requirements that must be fulfilled by structural adhesives and reinforcing materials; factors affecting performance and durability of bonded joints; and ways to improve adhesion and durability. Finally, it points out some research needs and future developments identified by the authors.

(c) Koninklijke Brill NV, Leiden, 2010
\end{abstract}

\section{Keywords}

Timber structures, rehabilitation, on-site polymerized adhesives, limitations, requirements, performance, durability, quality control

\footnotetext{
* To whom correspondence should be addressed. Tel.: 00351 218443295; Fax: 00351 218443071; e-mail: helenacruz@lnec.pt

(C) Koninklijke Brill NV, Leiden, 2010

DOI:10.1163/016942410X501089
} 